\title{
Genetic variability among broccoli genotypes based on biochemical and molecular traits
}

\author{
Osmar J Chaves Júnior ${ }^{1} \mathbb{D}$; Douglas M Zeffa ${ }^{2} \mathbb{D}$; Leonel V Constantino ${ }^{1} \mathbb{D}$; Renata $M$ Giacomin ${ }^{1} \mathbb{D}$; Rafael GB \\ Siqueira ${ }^{3 \mathbb{D}}$; Gabriel AB Silva ${ }^{3} \mathbb{D}$; Alison F Nogueira ${ }^{1} \mathbb{D}$; Leandro SA Gonçalves ${ }^{1} \mathbb{D}$; Maurício U Ventura ${ }^{1 \mathbb{D}}$
}

${ }^{1}$ Universidade Estadual de Londrina, Departamento de Agronomia (UEL), Londrina-PR, Brasil; osmarjcj@gmail.com; leonel@uel.br; giacomin.rm@gmail.com; alison.fernando@uel.br; leandrosag@uel.br; mventura@uel.br; ${ }^{2}$ Universidade Estadual de Maringá, Departamento de Agronomia, (UEM) Maringá-PR, Brasil; douglas.mz@hotmail.com; ㅈniversidade Estadual de Londrina, Departamento de Química (UEL), Londrina-PR, Brasil; rafa.beluce@gmail.com; gabrielbacinello110@gmail.com

\begin{abstract}
Broccoli (Brassica oleracea var. italica) is one of the most important vegetables in the world and also shows important functional properties. The present study aimed to characterize 19 broccoli genotypes using biochemical traits (content of total phenolic compounds, total flavonoids and antioxidant activity) and AFLP (Amplified Fragment Length Polymorphism) molecular markers. The experiment was carried out in a greenhouse using a complete randomized block design with three replicates. The phenotypic data were subjected to analysis of variance $(p \leq 0.05)$, Scott-Knott average clustering method $(p \leq 0.05)$ and principal component analysis (PCA). Using molecular data, Ward's hierarchical clustering, Bayesian clustering and principal coordinate analysis (PCoA) were performed. Molecular data showed genetic diversity among the genotypes (three groups), also a wide variability in the total phenolic compounds, total flavonoids content and antioxidant activity using FRAP method. HT3010, Hanabi and Bonanza genotypes showed desirable biochemical traits for the demanding functional food consumers, in addition to being promising genotypes to be exploited in plant breeding programs.
\end{abstract}

Keywords: Brassica oleracea var. itálica, phenolic compounds, breeding, horticulture, post-harvest.

\section{RESUMO}

Variabilidade genética entre genótipos de brócolis baseada em características bioquímicas e moleculares

Brócolis (Brassica oleracea var. italica) é umas das principais hortaliças do mundo e apresenta importantes propriedades funcionais. O presente estudo teve como objetivo caracterizar 19 genótipos de brócolis por meio de caracteres bioquímicos (teor de compostos fenólicos totais, flavonoides totais e atividade antioxidante) e marcadores moleculares do tipo AFLP (Amplified Fragment Length Polymorphism). O experimento foi realizado em casa de vegetação usando delineamento em blocos completos ao acaso com três repetições. Os dados fenotípicos foram submetidos à análise de variância $(p \leq 0,05)$, agrupamento de média de Scott-Knott $(p \leq 0,05)$ e análise de componentes principais (PCA). A partir dos dados moleculares, foram realizados os agrupamentos hierárquicos de Ward, agrupamento Bayesiano e análise de coordenadas principais (PCoA). Os dados moleculares indicaram diversidade genética entre os genótipos (três grupos), além de ampla variabilidade para o teor de compostos fenólicos totais, flavonoides totais e atividade antioxidante pelo método FRAP. Os genótipos HT3010, Hanabi e Bonanza apresentam características bioquímicas desejáveis aos consumidores exigentes em alimentos funcionais, além de serem genótipos promissores para serem explorados em programas de melhoramento da cultura.

Palavras-chave: Brassica oleracea var. itálica, compostos fenólicos, melhoramento genético, horticultura, pós-colheita.

\section{Received on March 5, 2021; accepted on May 27, 2021}

$\mathrm{B}$ roccoli (Brassica oleracea var. italica) is one of the most produced and consumed vegetables worldwide (Owis, 2015). This species is the result of the selection and accumulation of mutations during the domestication process of B. sylvestris. Its center of origin is the Mediterranean region (Stansell \& Björkman, 2020). Broccoli germplasm is divided into two main commercial groups: ramoso, which presents several small lateral inflorescences, and single-head broccoli, showing inflorescences concentrated at the shoot tip, also known as Japanese broccoli (Ordiales et al., 2017).

Broccoli consumption has been increasing in Brazil in the latest years, not only due to its reasonable price, making it affordable for different social classes, but also for its high nutritional value (Thomas et al., 2017). It is an important source of calcium, magnesium and essential amino acids (Melo, 2015; Chen et al., 2018). In addition, this vegetable presents antioxidants, mainly phenolic compounds, which contribute to the prevention of premature aging and various types of cancer and neurodegenerative diseases (Liu et al., 2018). Moreover, the phenolic compounds are part of several biochemical plant defense mechanisms 
related to biotic and abiotic stresses (Melo et al., 2017).

Phenotypic characterization is of great importance in order to indentify agronomic and/or superior nutritional traits (Swarup et al., 2021). In addition, molecular markers have been widely used to characterize genotypes, mainly to provide information on DNA genetic variability, as also avoiding influences concerning environment and/or plant development stage (Ahmad \& Anjum, 2018). Considering the molecular markers, the AFLP (Amplified Fragment Length Polymorphism) shows important characteristics, such as a large genome coverage, good reproducibility, low cost and high efficiency (Adhikari et al., 2017). Given the above, the aim of this study is to characterize broccoli genotypes using biochemical and molecular traits using AFLP markers.

\section{MATERIAL AND METHODS}

We evaluated 19 genotypes of broccoli, being 12 single-head broccoli genotypes and 7 ramoso broccoli genotypes (Table 1). The genotypes were sown on plastic trays with 128 cells and transplanted into 5-liter pots containing soil, organic compound and sand (3:1:1). The seedlings were transplanted 30 days after sowing, which means, when the plants reached $10-\mathrm{cm}$ in length and at least five definitive leaves. The experiment was carried out in a greenhouse in the experimental area of Universidade Estadual de Londrina (UEL), Londrina, Paraná,

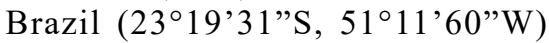
during the winter harvest, 2019. The experiment was carried out in a completely randomized design, with three replicates, consisting the plots of four plants.

Molecular characterization was carried out using AFLP technique, following the protocol proposed by Vos et al. (1995). DNA was extracted from a bulk of leaves of each cultivar using CTAB method (cetyltrimethylammonium bromide, Sigma-Aldrich, MissouriUSA). Approximately $500 \mathrm{ng}$ of this DNA was double digested with $1 \mathrm{U}$ MseI and 5 U EcoRI (Thermo Scientific,
Califórnia, USA) and linked to EcoRI $(0.5 \mu \mathrm{M})$ and MseI $(5 \mu \mathrm{M})$ adapters in a reaction containing: T4 DNA ligase (2U); $1 \mathrm{X}$ T4 DNA ligase buffer; $\mathrm{NaCl}$ (0.05M); BSA (50 $\left.\mu \mathrm{g} \mu \mathrm{L}^{-1}\right)$; DTT $(0.25$ $\mathrm{mM}$ ) to a final volume of $10 \mu \mathrm{L}$. The established program for the digestionbinding step consisted of: $37^{\circ} \mathrm{C}$ for $4 \mathrm{~h}$, $22^{\circ} \mathrm{C}$ for $1 \mathrm{~h}$ and $70^{\circ} \mathrm{C}$ for $10 \mathrm{~min}$. The digestion/binding pattern was visualized on a $1 \%$ agarose gel. After confirmation of digestion, the amplified product was diluted 1:4 with ultrapure water. Preselective amplification was performed using $3.5 \mu \mathrm{L}$ of the GoTaq ${ }^{\circledR}$ Green Master Mix (Promega, WinchesterUSA), $0.58 \mu \mathrm{L}$ of the pre-selective primers EcoRI $+\mathrm{A}$ and MseI $+\mathrm{C}$ $(4.75 \mu \mathrm{M}), 3.0 \mu \mathrm{L}$ of the dilution of the restriction-binding reaction and ultrapure water to complete the $10 \mu \mathrm{L}$ volume. The pre-selective amplification program consisted of 1 cycle of $72^{\circ} \mathrm{C}$ for $2 \mathrm{~min}, 20$ cycles of $94^{\circ} \mathrm{C}$ for $1 \mathrm{~s}, 56^{\circ} \mathrm{C}$ for $30 \mathrm{~s}, 72^{\circ} \mathrm{C}$ for $2 \mathrm{~min}$ and a final cycle of $60^{\circ} \mathrm{C}$ for $30 \mathrm{~min}$. Pre-selective PCR confirmation was confirmed on a $2 \%$ agarose gel and the amplified product was diluted 1:8 in ultrapure water.

Four primer combinations were selected for the selective amplification assay: a) EcoRI (FAM)/-ATC/MseICTCG, b) EcoRI (NED) - AGC/ MseI-CAA, c) EcoRI (VIC) - ACT/ MseI-GAG and d) EcoRI (PET) - AGC/ MseI -CAC. The selective reactions were performed in a $10 \mu \mathrm{L}$ volume containing: $3.5 \mu \mathrm{L}$ of PCR master mix (GoTaq ${ }^{\circledR}$ Green Master Mix, Promega, Winchester-USA), $0.54 \mu \mathrm{L}$ of each MseI primer $(5 \mu \mathrm{M})$ and EcoRI $(1 \mu \mathrm{M}), 2.5$ $\mu \mathrm{L}$ of diluted pre-amplification reaction and $2.92 \mu \mathrm{L}$ of ultrapure water. The amplification program consisted of 1 cycle of $94^{\circ} \mathrm{C}$ for $2 \mathrm{~min}, 65^{\circ} \mathrm{C}$ for $30 \mathrm{~s}$ and $72^{\circ} \mathrm{C}$ for $2 \mathrm{~min} ; 8$ cycles of $94^{\circ} \mathrm{C}$ for $1 \mathrm{~s}, 64^{\circ} \mathrm{C}$ for $30 \mathrm{~s}$ and $72^{\circ} \mathrm{C}$ for 2 min; 23 cycles of $94^{\circ} \mathrm{C}$ for $1 \mathrm{~s}, 56^{\circ} \mathrm{C}$ for $30 \mathrm{~s}$ and $72^{\circ} \mathrm{C}$ for $2 \mathrm{~min}$ and 1 final cycle of $60^{\circ} \mathrm{C}$ for $30 \mathrm{~min}$. Fragment resolution was performed by capillary electrophoresis using the automatic DNA analyzer model 3500xL (Applied Biosystems, California-USA) and the fragment electrophoresis results were combined in a binary matrix by the GeneMapper ${ }^{\circledR}$ v.4.1 software (Applied
Biosystems, California, USA).

The characterization of bioactive compounds was performed by quantifying the total phenolic content (TPC), total flavonoid content (TFC) and antioxidant activity using the FRAP (ferric reducing antioxidant power) assay (Benzie \& Strain, 1999). The samples consisted of harvesting the broccoli inflorescences, which were immediately frozen in liquid nitrogen and then lyophilized. After drying, the samples were ground in a WSG30 mill (Waring, USA), sieved in 80 mesh and stored in polyethylene pots protected from light and heat. For the extraction of TPC, TFC and FRAP, a suspension was prepared from $1.00 \mathrm{~g}$ of the lyophilized sample in $10.0 \mathrm{~mL}$ of $70 \%$ ethanol $(\mathrm{v} / \mathrm{v})$ with five replicates, according to the protocol adapted by Vázquez et al. (2008).

TPC quantification was performed according to Swain \& Hillis (1959) using gallic acid as analytical standard, ranging from 10 to $100 \mathrm{mg} \mathrm{L}^{-1}(\mathrm{r}=$ 0.9960 ), expressed as milligrams of gallic acid equivalent per 100 grams (mg GAE $100 \mathrm{~g}^{-1}$ ). TFC quantification was based on Gurnani et al. (2016) using quercetin as analytical standard, ranging from 50 to $500 \mathrm{mg} \mathrm{L}^{-1}(\mathrm{r}=0.9942)$, expressed as equivalent milligrams of quercetin $100 \mathrm{~g}^{-1}\left(\mathrm{mg}\right.$ QE $\left.100 \mathrm{~g}^{-1}\right)$. FRAP was quantified based on Benzie \& Strain (1999) using trolox (6-hydroxy-2,5,7,8tetramethylchroman-2-carboxylic acid) as analytical standard, ranging from 0.20 to $1.00 \mathrm{mmol} \mathrm{L}^{-1}$ ( $\left.\mathrm{r}=0.9992\right)$, expressing as $\mu \mathrm{mol}$ of antioxidant capacity equivalent to trolox per $100 \mathrm{~g}$ $\left(\mu \mathrm{mol}\right.$ TEAC $\left.100 \mathrm{~g}^{-1}\right)$.

After being verified the normality and homogeneity of variances, the biochemical characterization data were submitted to analysis of variance (ANOVA) and when significant $(p \leq 0.05)$, the averages were clustered using Scott-Knott test $(p \leq 0.05)$. Principal Component Analysis (PCA) was performed using the standardized average Euclidean distance. These analyses were performed using $\mathrm{R}$ software (https://www.r-project.org/) version 3.6.0 using 'Expdes.pt' and 'FactoMiner' packages.

Using the AFLP markers, population 
genetics structure was verified by Bayesian clustering using Structure software version 2.3.4 (Pritchard et al., 2000), based on the method described by Evanno et al. (2005). We used 500,000 MCMC iterations (Monte Carlo Markov chain), a burnin period of 100,000 iterations, with admixture model and correlated allelic frequencies. Subgroups values $(\Delta K)$ from 1 to 19 were tested, with ten independent interactions for each value of $\mathrm{K}$. The ideal number of $\mathrm{K}$ was determined using Structure Harvester software version 0.6.92 (Earl, 2012). The analysis of principal coordinates (PCoA) was performed using the $\mathrm{R}$ software version 3.6.0 through the 'ape' and 'plot3D' packages. Additionally, the Jaccard distance between cultivars was calculated and Ward's hierarchical grouping was performed using the 'philentropy', 'factoextra' and 'ggplot2' packages.

\section{RESULTS AND DISCUSSION}

The authors verified that AFLP markers are efficient to detect the genetic variability among the broccoli genotypes evaluated in this study. The four primer combinations resulted in 409 amplified bands, all of which are polymorphic. These results are superior to the ones observed by Lin et al. (2013), studying the genetic diversity among broccoli accessions based on nine primer combinations AFLP; these authors observed a total of 334 amplified bands, being 208 (62.3\%) polymorphic. AFLP methodology associated with automated capillary electrophoresis system has been considered an important tool for exploring the genetic divergence in several vegetable species (Cardoso et al., 2018; Constantino et al., 2020; Massucato et al., 2020).

Ward's hierarchical grouping, Bayesian clustering and the analysis of principal coordinates (PCoA) of the 19 broccoli genotypes are observed in Figure 1 . The average similarity $\left(d^{\prime}\right)$ among these evaluated genotypes was 0.560 , being the cultivars Maraton and Domador genetically closest $\left(d^{\prime}=0,289\right)$, whereas the genotypes Seminis002 and
Hanabi are the most distant $\left(d^{\prime}=0,774\right)$. Considering the simulations performed using $\Delta \mathrm{K}$ value method (Evano et al., 2005), we observed an optimal number of $\mathrm{K}=3$, indicating the formation of three distinct groups.

Group 1 (green) was formed by nine genotypes (Crioulo 2, Seminis002, Avenger, AF1125, Domador, Maraton, Seminis001, HT9631F1 and HT3010). Groups 2 (red) and 3 (blue) consisted of four genotypes (Bonanza, HT1607, Calabres and AF1957) and six genotypes [Piracicaba Precoce (Horticeres), Piracicaba Precoce (Sakata), Hanapon, Santana, Akemi ande Hanabi], respectively. The genotypes Crioulo 2, AF1125, Bonanza and AF1957 were classified as admixture, since none of them showed ancestry coefficient greater than 0.6 for no group.

The first three main coordinates (PCoA1, PCoA2 and PCoA3) explained $45.09 \%$ of the total variation among the evaluated genotypes. Using PCoA, it is possible to observe that the genotype clustering was similar to the one observed through Bayesian clustering and Ward's hierarchical grouping, showing consistency among these three clustering approaches with molecular data. The results of molecular characterization are consistent with traits related to the types of inflorescences of the studied genotypes, since the genotypes in group 2 (red) are singleheaded inflorescence genotypes, whereas genotypes in group 3 (blue) are ramoso inflorescence genotypes. The genotypes in group 1 (green) are all single-headed, except Crioulo 2 . However, this accession was considered mixed by Bayesian clustering, indicating that it shares alleles from groups 1 and 3 .

The averages of the evaluated biochemical traits are shown in Table 2 . The antioxidant activity determined by FRAP assay ranged between 16.80 (Seminis001) and $56.24 \mu \mathrm{mol}$ TEAC $100 \mathrm{~g}^{-1}$ (HT3010), whereas the contents of phenolic compounds ranged between 22.97 (Seminis001 and AF1957) and

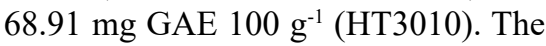
total flavonoid contents ranged between 41.06 (Hanapon) and 61.67 mg QE 100 $\mathrm{g}^{-1}$ (HT3010). In general, the contents of total phenolic compounds and the antioxidant activity determined by FRAP assay were higher in singleheaded inflorescence genotypes when

Table 1. Traits of 19 broccoli genotypes evaluated in this study. Londrina, UEL. 2019.

\begin{tabular}{lccc}
\hline Genotype & Company & Inflorescence & Type \\
\hline Marathon & Sakata & Single head & Cultivar \\
Hanapon & Sakata & Ramoso & Cultivar \\
Hanabi & Sakata & Ramoso & Cultivar \\
AF1125 & Sakata & Single head & Inbred line \\
Avenger & Sakata & Single head & Cultivar \\
AF1957 & Sakata & Single head & Inbred line \\
Piracicaba Precoce & Sakata & Ramoso & Cultivar \\
HT3010 & Bioseeds & Single head & Inbred line \\
HT9631F1 & Bioseeds & Single head & Inbred line \\
HT1607 & Biosseds & Single head & Inbred line \\
Calabres & Feltrin & Single head & Cultivar \\
Akemi & Horticeres & Ramoso & Cultivar \\
Piracicaba Precoce & Hoticeres & Ramoso & Cultivar \\
Domador & Horticeres & Single head & Cultivar \\
Seminis001 & Seminis & Single head & Inbred line \\
Seminis002 & Seminis & Single head & Inbred line \\
Bonanza & Isla & Single head & Cultivar \\
Santana & Isla & Ramoso & Cultivar \\
Crioulo 2 & - & Ramoso & Landrace \\
\hline
\end{tabular}


compared to the ramoso-type genotypes. None of the commercial groups showed a greater differentiation in terms of flavonoid contents.

Studying the bioactive compounds in Brassica oleracea L. var. acephala, Rigueira et al. (2016) observed high contents of phenolic compounds (173 and $244 \mathrm{mg}$ GAE $100 \mathrm{~g}^{-1} \mathrm{~g}$ in leaves and 86 and $180 \mathrm{mg}$ GAE $100 \mathrm{~g}^{-1}$ in stems) and the average antioxidant activity was 62.5 and $34.5 \%$ in leaves and stalks, respectively. We concluded that, in addition to the genetic variability existing among genotypes, the cultivation system also influences the concentration of bioactive compounds. Moreover, other factors such as part of the plant, phenological stage and crop management can also influence the concentration of these bioactive compounds (Rigueira et al., 2016; Batista et al., 2017; Nasser et al., 2020; Zanzini et al., 2020).
The two first main components (PC1 and $\mathrm{PC} 2$ ) showed a total of 70.7 and $21.8 \%$ of total variation, respectively (Figure 2). Using PCA, we could observe that cultivars Hanabi and AF1125 showed interesting accessions for studies related to flavonoids, since they showed high averages for this trait (Figure 2, Table 2). Cultivars Akemi and Bonanza were associated with the antioxidant activity trait vector determined by FRAP method, presenting
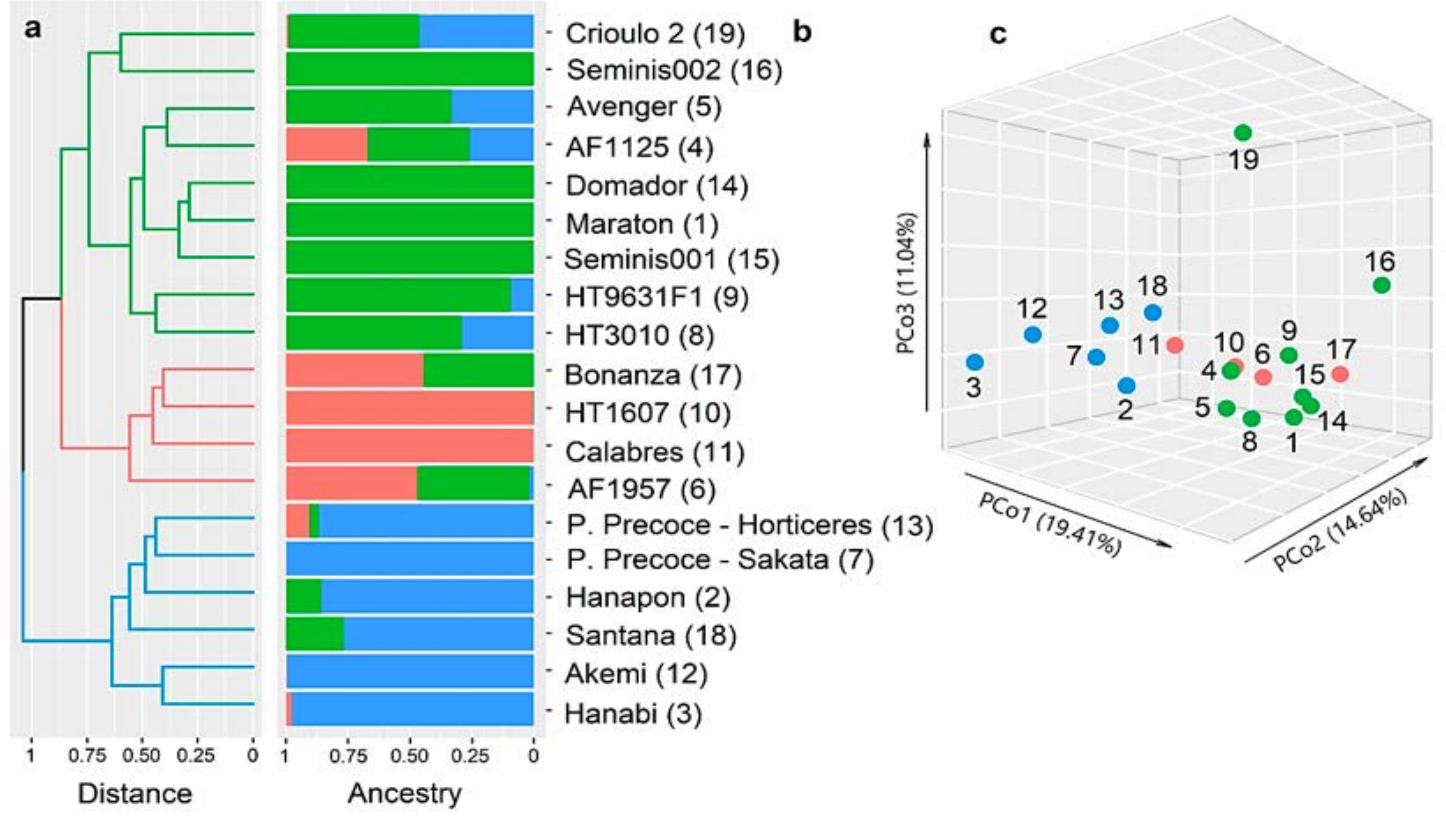

Figure 1. Ward's hierarchical grouping (a), Bayesian clustering considering $\mathrm{K}=3$ (b) and the analysis of principal coordinates (c) of 19 broccoli cultivars. Londrina, UEL, 2019.

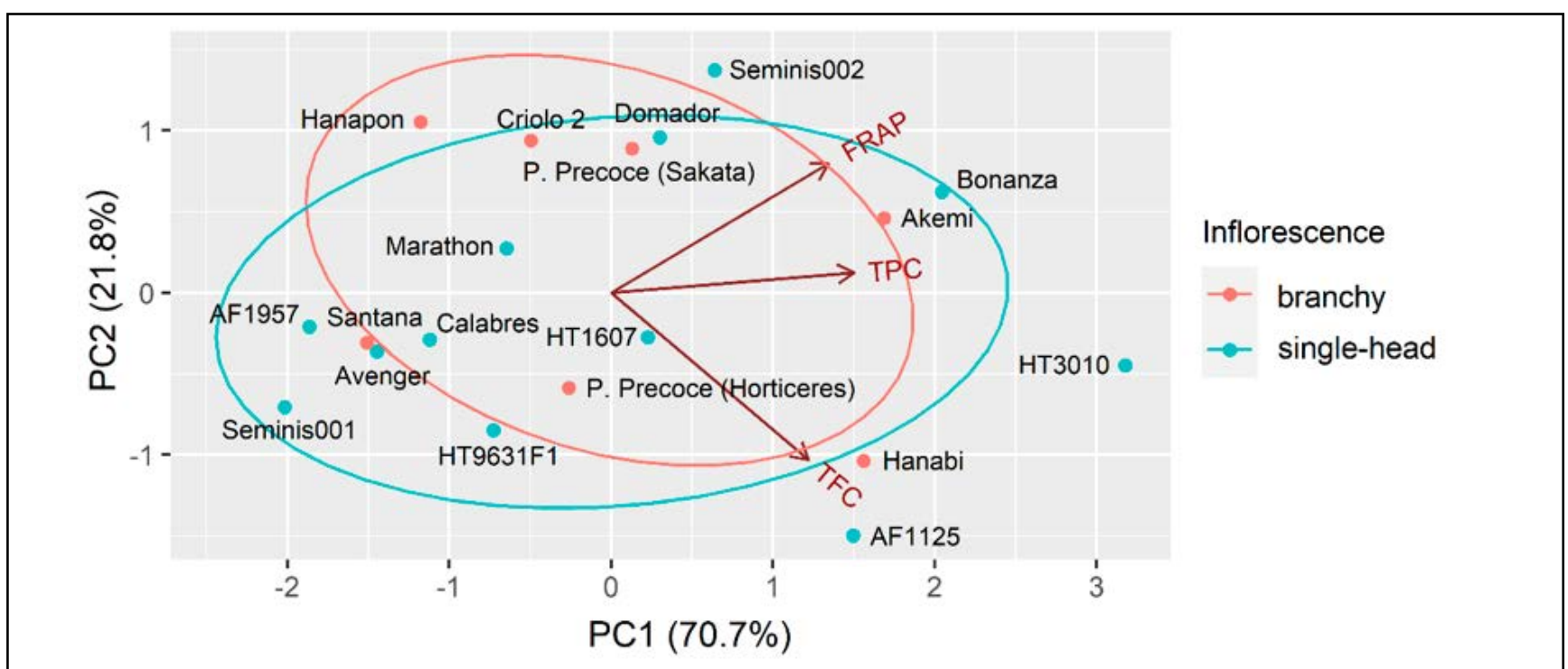

Figure 2. Principal Component Analysis (ACP) of 19 broccoli genotypes evaluated for antioxidant activity (FRAP), content of total phenolic compounds (TPC) and total flavonoids (TFC). Londrina, UEL, 2019. 
Table 2. Averages and standard deviation of antioxidant activity (FRAP), content of total phenolic compounds (TPC) and total flavonoids (TFC) of 19 broccoli genotypes. Londrina, UEL. 2019.

\begin{tabular}{lccc}
\hline Genotypes & FRAP & TPC & TFC \\
\hline Maraton & $29.77 \pm 2.52 \mathrm{c}$ & $42.86 \pm 2.41 \mathrm{~d}$ & $45.00 \pm 4.08 \mathrm{c}$ \\
Hanapon & $37.33 \pm 3.03 \mathrm{c}$ & $31.93 \pm 1.39 \mathrm{f}$ & $41.06 \pm 3.37 \mathrm{c}$ \\
Hanabi & $40.03 \pm 3.66 \mathrm{~b}$ & $53.78 \pm 5.45 \mathrm{~b}$ & $59.55 \pm 2.81 \mathrm{a}$ \\
AF1125 & $34.09 \pm 0.97 \mathrm{c}$ & $55.18 \pm 2.10 \mathrm{~b}$ & $61.06 \pm 2.48 \mathrm{a}$ \\
Avenger & $21.12 \pm 3.33 \mathrm{e}$ & $31.93 \pm 5.55 \mathrm{f}$ & $46.21 \pm 0.94 \mathrm{c}$ \\
AF1957 & $23.28 \pm 2.43 \mathrm{~d}$ & $22.97 \pm 2.62 \mathrm{~g}$ & $45.30 \pm 0.94 \mathrm{c}$ \\
P, Precoce & $51.92 \pm 1.75 \mathrm{a}$ & $34.17 \pm 3.28 \mathrm{f}$ & $47.73 \pm 4.08 \mathrm{c}$ \\
(Sakata) & $56.24 \pm 4.45 \mathrm{a}$ & $68.91 \pm 2.92 \mathrm{a}$ & $61.67 \pm 4.29 \mathrm{a}$ \\
HT3010 & $26.53 \pm 1.46 \mathrm{~d}$ & $31.93 \pm 3.67 \mathrm{f}$ & $51.97 \pm 2.48 \mathrm{~b}$ \\
HT9631F1 & $42.73 \pm 0.84 \mathrm{~b}$ & $34.45 \pm 1.05 \mathrm{f}$ & $53.48 \pm 2.48 \mathrm{~b}$ \\
HT1607 & $25.99 \pm 0.49 \mathrm{~d}$ & $32.21 \pm 4.10 \mathrm{f}$ & $47.42 \pm 2.48 \mathrm{c}$ \\
Calabres & $52.46 \pm 4.31 \mathrm{a}$ & $57.42 \pm 1.39 \mathrm{~b}$ & $52.58 \pm 2.48 \mathrm{~b}$ \\
Akemi & $30.31 \pm 2.22 \mathrm{c}$ & $38.66 \pm 2.92 \mathrm{e}$ & $51.67 \pm 2.81 \mathrm{~b}$ \\
P,Precoce & $47.60 \pm 2.70 \mathrm{~b}$ & $44.26 \pm 3.19 \mathrm{~d}$ & $46.21 \pm 3.37 \mathrm{c}$ \\
(Hoticeres) & $16.80 \pm 1.75 \mathrm{e}$ & $22.97 \pm 3.96 \mathrm{~g}$ & $46.82 \pm 2.48 \mathrm{c}$ \\
Domador & $52.46 \pm 2.70 \mathrm{a}$ & $49.02 \pm 1.82 \mathrm{c}$ & $45.00 \pm 3.37 \mathrm{c}$ \\
Seminis001 & $54.08 \pm 3.66 \mathrm{a}$ & $63.87 \pm 1.82 \mathrm{a}$ & $52.27 \pm 0.94 \mathrm{~b}$ \\
Seminis002 & $17.34 \pm 2.95 \mathrm{e}$ & $36.69 \pm 3.67 \mathrm{e}$ & $44.70 \pm 4.29 \mathrm{c}$ \\
Bonanza & $34.09 \pm 4.20 \mathrm{c}$ & $47.90 \pm 1.05 \mathrm{c}$ & $41.67 \pm 3.37 \mathrm{c}$ \\
Santana & 8.21 & 6.61 & 6.35 \\
Crioulo 2 & CV (\%) & & \\
\hline Avemges & & & \\
\hline
\end{tabular}

Averages followed by the same letter in the lines do not statistically differ from each other by the Scott-Knott test at 5\% significance.

high averages for these traits. Among the evaluated genotypes, HT3010 was the genotype which presented the highest averages for the antioxidant activity using FRAP assay, content of total phenolic compounds and content of total flavonoids. No difference between ramoso or single-headed inflorescence genotypes was observed through PCA.

The genetic variability shown in the studied broccoli genotypes observed using AFLP markers and biochemical traits can be explored in broccoli breeding programs. Among the evaluated genotypes, the genotypes HT3010, Hanabi, Bonanza, Akemi and AF1125 stood out as they presented the highest contents of antioxidant activity using FRAP assay, total phenolic compounds and total flavonoids. These genotypes can be used as parents in breeding programs aiming to develop broccoli cultivars with high contents of active compounds.

\section{REFERENCES}

ADHIKARI, S; SAHA, S; BISWAS, A; RANA, TS; BANDYOPADHYAY, TK; GHOSH, P. 2017. Application of molecular markers in plant genome analysis: a review. The Nucleus, 60: 283-297. https://doi.org/10.1007/s13237017-0214-7

AHMAD, R; ANJUM, MA. 2018. Applications of molecular markers to assess genetic diversity in vegetable and ornamental crops - a review. Journal of Horticultural Science and Technology, 1: 1-7. https://doi.org/10.46653/ jhst 180101001

BATISTA, CFT; SILVA, CO; MELO, CMT; TASSI, EMM; PASCOAL, GB. 2017. Alterações nutricionais e físico-químicas em repolho branco (Brassica oleracea) após o processamento mínimo e durante o armazenamento. Demetra. 12: 305-318. https://doi.org/10.12957/demetra.2017.22115 BENZIE, IF; STRAIN, JJ. 1999. Ferric reducing/ antioxidant power assay: direct measure of total antioxidant activity of biological fluids and modified version for simultaneous measurement of total antioxidant power and ascorbic acid concentration. Methods in enzymology 299: 15-27. https://doi. org/10.1016/S0076-6879(99)99005-5

CARDOSO, R; RUAS, CF; GIACOMIN, RM; RUAS, PM; RUAS, EA; BARBIERI, RL; GONÇALVES, LSA. 2018. Genetic variability in Brazilian Capsicum baccatum germplasm collection assessed by morphological fruit traits and AFLP markers. PloS one 13: e0196468. https://doi.org/10.1371/journal. pone. 0196468

CHEN, L; ZHAO, B; FAN, Z; LIU, X., WU, Q; LI, H; WANG, H. 2018. Synthesis of novel 3, 4-chloroisothiazole-based imidazoles as fungicides and evaluation of their mode of action. Journal of Agricultural and Food Chemistry 66: 7319-7327.

CONSTANTINO, LV; FUKUJI, AYS; ZEFFA, DM; BABA, VY; CORTE, ED; GIACOMIN, RM; GONÇALVES, LSA. 2020. Genetic variability in peppers accessions based on morphological, biochemical and molecular traits. Bragantia 79: 443-446. https://doi. org/10.1590/1678-4499.20190525

EARL, DA. 2012. STRUCTURE HARVESTER: a website and program for visualizing STRUCTURE output and implementing the Evanno method. Conservation Genetics Resources 4: 359-361. DOI:10.1007/s12686011-9548-7

EVANNO, G; REGNAUT, S; GOUDET, J. 2005. Detecting the number of clusters of individuals using the software STRUCTURE: a simulation study. Molecular Ecology 14: 2611-2620. https://doi.org/10.1111/j.1365294X.2005.02553.x

GURNANI, N; GUPTA, M; MEHTA, D; MEHTA, BK. 2016. Chemical composition, total phenolic and flavonoid contents, and in vitro antimicrobial and antioxidant activities of crude extracts from red chilli seeds (Capsicum frutescens L.). Journal of Taibah University for Science 10: 462-470. https://doi.org/10.1016/j. jtusci.2015.06.011

LIN, KH; CHANG, LC; LAI, CD; LO, HF. 2013. AFLP mapping of quantitative trait loci influencing seven head-related traits in broccoli (Brassica oleracea var. italica). The Journal of Horticultural Science and Biotechnology 88: 257-268. https://doi.org/1 0.1080/14620316.2013.11512964

LIU, M; ZHANG, L; SER, SL; CUMMING, JR; KU, KM. 2018. Comparative phytonutrient analysis of broccoli by-products: The potentials for broccoli by-product utilization. Molecules 23: 900. https://doi.org/10.3390/ molecules 23040900

MASSUCATO, LR; NAKAMURA, KK; RUAS, PM; ZEFFA, DM; SILVA, DJHD; GONÇALVES, LSA. 2020. Genetic diversity among Brazilian okra landraces detected by morphoagronomic and molecular descriptors. Acta Scientiarum. Agronomy 42. http://dx.doi. org/10.4025/actasciagron.v42i1.43426

MELO, RAC. 2015. A cultura do brócolis. 
Brasília, DF: Embrapa, 153p.

MELO, TA; ARAUJO, MUP; SERRA, IMRS; PASCHOLATI, SF. 2017. Produtos naturais disponíveis comercialmente induzem o acúmulo de fitoalexinas em cotilédones de soja e mesocótilos de sorgo. Summa Phytopathologica, 43: 205-211. https://doi. org/10.1590/0100-5405/167358

NASSER, MD; CARDOSO, AII; VIEITES, RL; NASSER, FADCM; FURLANETO, KA; RAMOS, JA; SANTOS, JA. 2020. Compostos bioativos e caracterização físico-química da couve-de-folha sob composto orgânico, gessagem e doses de enxofre em cobertura. Scientia Plena 16. https://doi.org/10.14808/ sci.plena.2020.090201

ORDIALES, E; IGLESIAS, DJ; ALARCÓN, MV; ZAJARA, L, GIL, J; GUTIÉRREZ, JI; SALGUERO, J. 2017. Characteristics defining broccoli cultivars from different seed producers. International Journal of Agronomy. https://doi.org/10.1155/2017/8216390

OWIS, AI. 2015. "Broccoli; the green beauty: a review." Journal of Pharmaceutical Sciences and Research: 7: 696.

PRITCHARD, JK; STEPHENS, M; DONNELLY, P. 2000. Inference of population structure using multilocus genotype data. Genetics 155: 945-959. https://doi.org/10.1093/ genetics/155.2.945

RIGUEIRA, GDJ; BANDEIRA, AVM; CHAGAS, CGO; MILAGRES RCRM. 2016. Atividade antioxidante e teor de fenólicos em couvemanteiga (Brassica oleracea L. var. acephala) submetida a diferentes sistemas de cultivo e métodos de preparo. Semina: Ciencias Biológicas e da Saúde. 37: 3-2. http://dx.doi. org/10.5433/1679-0367.2016v37n2p3

STANSELL, Z; BJÖRKMAN, T. 2020. From landrace to modern hybrid broccoli: the genomic and morphological domestication syndrome within a diverse B. oleracea collection. Horticulture Research 7: 1-17. https://doi.org/10.1038/s41438-020-00375-0

SWAIN, T; HILLIS, WE. 1959. The phenolic constituents of Prunus domestica. I.-The quantitative analysis of phenolic constituents. Journal of the Science of Food and Agriculture 10: 63-68. https://doi.org/10.1002/ jsfa. 2740100110

SWARUP, S; CARGILL, EJ; CROSBY, K; FLAGEL, L; KNISKERN, J; GLENN, KC. 2021. Genetic diversity is indispensable for plant breeding to improve crops. Crop Science 61: 839-852. https://doi.org/10.1002/ $\csc 2.20377$

THOMAS, M; BADR, A; DESJARDINS, Y; GOSSELIN, A; ANGERS, P. 2017.
Characterization of industrial broccoli discards (Brassica oleracea var. italica) for their glucosinolate, polyphenol and flavonoid contents using UPLC MS/MS and spectrophotometric methods. Food Chemistry 245: 1204-1211. https://doi.org/10.1016/j. foodchem.2017.11.021

VÁZQUEZ, G; FONTENLA, E; SANTOS, J; FREIRE, MS; GONZÁLEZ-ÁLVAREZ, J; ANTORRENA, G. 2008. Antioxidant activity and phenolic content of chestnut (Castanea sativa) shell and eucalyptus (Eucalyptus globulus) bark extracts. Industrial Crops and Products 28: 279-285. https://doi. org/10.1016/j.indcrop.2008.03.003

VOS, P; HOGERS, R; BLEEKER, M; REIJANS, M; LEE, T; VAN, DE; HORNES, M; FRITERS, A; POT, J; PALEMAN, J; KUIPER, M. 1995. AFLP: a new technique for DNA fingerprinting. Nucleic Acids Research 23: 4407-4414. https://doi.org/10.1093/ nar/23.21.4407

ZANZINI, AP; OLIVEIRA, JAC; COUTINHO, GSM; ARAUJO, ABS; BARROS, HEA. 2020. Bioactive compounds present in kale (Brassica oleracea L.) at three stages of development and comparison of their antioxidant capacities. Research, Society and Development. 9: e391974242. https://doi.org/10.33448/rsdv9i7.4242 